\title{
The Place of Commercial Diplomacy in Nigeria-China Relations
}

\author{
IBRAHIM Abu Akoh* \\ Department of Political Science and International Studies, Ahmadu Bello University, Zaria, Nigeria
}

\begin{abstract}
Analysis of Nigeria and China relations has often been generalized with the best effort to break this down ending with economic diplomacy, yet this diplomatic relations encompass many aspects with its simultaneously agonizing and palatable consequences. This article analysed the contribution of commercial diplomacy in strengthening the overall relations between Nigeria and China. This was done not only for the singular purpose of bringing to the fore this almost neglected part of the relations but to also emphasis the danger of the overwhelming proliferation of Chinese goods in Nigerian Markets. The article used secondary data supported by empirical information from relevant bodies. The paper argues that the chief reason why China entered into diplomatic relations with Nigeria is for the exploitation of its large consumer population. Thus in analysing Nigeria-China relations emphasis should be on the commercial element .The conclusion derived from the available evidence is that Nigeria-China commercial diplomacy is a major contributory factor for the decline of the manufacturing sector in Nigeria. Hence, this paper advocates a renegotiation of the terms of commercial diplomacy between the two countries and the institutionalization of trade restrictions on the importation of goods that are produced in Nigeria.
\end{abstract}

Keywords: China, Commercial diplomacy, Nigeria, Place, Relations

\section{Introduction}

In contemporary diplomacy, an increasing number of countries' diplomatic arrangements are being revamped so that commercial activities have become the nucleus of diplomatic relations; the commercial activities of diplomats have been expanded and business interests have become part of the diplomatic system (Lee and Hudson, 2004). Thus, in this era of economic globalization, it has become imperative for any country engaged in diplomatic relations to emphasis the commercial dimension. Nigeria has over the last few decades made this consciously or unconsciously, a dominant part of her relations with China. This has seen the penetration and rapid proliferation of Nigerian markets by Chinese goods. Scholars on Nigeria- China Economic relations have over the years given undue glory to Chinese investments and aid to Nigeria thereby neglecting the importance of trade which has been the driving force of Nigeria's relations with China (Ogunkola, et al., 2009; Adekola, 2010; Osakwe, 2012; Utomi,2012).

Foreign trade has been a major tool in the development strategies of many nations around the world. The workings of an economy are the conglomeration of its domestic production, consumption together with international transactions of goods and services (Akeem, 2011). Therefore, Nigeria's intercourse with China in terms of trade is not incongruous with the prevailing terrain. But, contrary to the postulations prevalent among scholars on this relation that China's engagements with Nigeria has led to the rapid transformation of the economy and society of the latter, this fellowship has made the Nigerian economy an import dependent economy, thereby hampering its continuous quest for self-reliance and economic independence.

Nabine, (2012), writing on the impact of Chinese Investment and Trade on the Nigerian Economy, came to a conclusion that in the short term, the bilateral trade does not contribute to Nigeria's economic growth but the long term relationship will. He thus failed to admit that this bilateral relation is not only economic growth deficient but has to a large extent retarded the economy. Personal observation has revealed that most of Nigeria's household utensils, office equipment, textile materials, electronic and telecommunication accessories, pharmaceutical products, to mention just a few, are imported from China. Hence, continually, Nigeria's manufacturing sector which should be the driving force of any developing economy is sinking to a state of comatose. China prefers trade to investment because of its ever expanding manufacturing sector and the need to find market for the disposal of its cheaply manufactured goods coupled with its vociferous oil demands.

Consequently, in the last two decades, Nigeria has experienced a momentous decline in manufacturing, losing approximately 8,707 manufacturing jobs due to collapse and relocation of manufacturing companies (Ayeni, 2012) in submission to the insurmountable competition with cheaply manufactured Chinese goods worsened by poor infrastructural facilities. For Osakwe, (2012), China is valuable for Nigeria in view of the escalation, according to her, of the establishment of infrastructure, intensification of skill and human capital. Again, in her analysis of this relation, she failed to examine the commercial element. Accordingly, she glorified 
profusely, China's interest in Nigeria. But the available evidence shows that primarily, the platform on which Nigeria and China relate is commerce.

Prior to 1980, China was one of the poorest countries in the world. The rise of China from a poor and stagnant country to be one of the major world economic power houses has been described as the greatest economic success of the modern time. Before this period, China maintained a centrally planned otherwise called command economy where a large share of the nation's economic output was directed and controlled by the state which set production goals and controlled prices and allocated resources for the most part of the economy. Following Deng Xiaopeng's reform policies of the 1970s and 80s, China's dramatic growth and modernization, and attendant industrial, energy, and market expansion needs, brought it into greater contact with AfricaNigeria (Utomi, 2012). In other words, when China was at the present level of economic development, it focused on inward transformation of her economy and exercised relative level of isolation from the world. It enjoyed a variety of trade restrictions. Regrettably, Nigeria with her features of a weak state has now become the export destination of cheap China made goods. If China needed trade control and restriction to develop to this level, Nigeria needs it even more. In the history of economic development, no nation has ever developed in the presence of uncontrolled importation especially of consumables.

This forms the basis of this paper. It first of all seeks to answer the following questions: What is the significance of commercial diplomacy in the overall China-Nigeria relations? How beneficial has this been to Nigerian economy? Finally, what effort has Nigeria made to maximize this aspect of the relations?

To effectively carry out this task, this work is divided into five short sections. The first part introduces the work. This is followed by a section detailing on the concept of diplomacy; economic diplomacy and commercial diplomacy. Here, attempt will be made to distinguish between economic diplomacy and commercial diplomacy. The next section gives a brief background to Nigeria-China relations. The second to the last part which is the core of this thesis, dwells on the evaluation of Nigeria-China commercial diplomacy and a brief conclusion drawn from the findings of this analysis follows.

\section{Diplomacy}

Diplomacy is usually described as the primary instrument of foreign policy through which a country; sovereign state that is, maintains its external relations with foreign governments. In the traditional definition given by (Bull, 1995) ${ }^{1}$, diplomacy is seen as the conduct of relations between states and other entities recognized in world politics by official agents and by peaceful means. The conception of diplomacy changes in line with changes and developments in the international system. More recently, Barridge and James $(2003)^{2}$ defined it as the conduct of relations between sovereign states through the medium of officials based at home or abroad and the basic means by which states communicate with each other enabling them to have regular and complex relations. International relations has transformed over the years such that the influence of nongovernmental organisations in decision making can no longer be neglected. This informed Melisssen's definition which sees diplomacy as the instrument of representation, communication and negotiation through which states and other international actors conduct their businesses (Melissen, 1999). In a more general sense however, diplomacy could be defined as the institutions and processes by which states and others represent themselves and their interests to one another. Or, it is the act and practice of conducting negotiations between representatives of groups or states. It is done through the intercession of professional diplomats with regards to issues of peace-making, trade, economics, culture, environment, and Human rights.

\subsection{Commercial Diplomacy: Towards conceptual clarifications}

The concept of commercial diplomacy has been erroneously neglected by scholars of diplomacy. This is done by subsuming the concept within the margins of economic diplomacy. This implies that in a large chunk of the available literature on diplomacy, commercial diplomacy has hardly received any independent attention other than the mention being made of it in the general discourses on economic diplomacy. This is in spite of the fact that economic diplomacy as history has it, owes its origin to commercial relations among societies (Sanar and Yiu, 2001). Some studies which apparently are concerned with economic diplomacy are, as a consequence of lack of this distinction, wrongly titled commercial diplomacy. While these concepts of diplomacy are closely interrelated, they are not quite the same. Commercial diplomacy is a subset of the wider compendium of economic diplomacy and as such it cannot take the place of economic diplomacy and despite their close interrelatedness, it is important to make an attempt to draw a thin margin between these two most common concepts of diplomacy. Additionally, with the growing spate of international trade, commercial diplomacy has assumed a staggering influence in the scheme of things such that it deserves an independent study.

Commercial diplomacy has been defined as the service provided usually by the staff members of a diplomatic mission focused on the promotion of business and investment between host and home countries (Narray,2008). It is concerned with business intelligence which comprises both data collection and analysis for the business class of the home community and in some cases foreign investors and traders. Also Sanar and Yiu, 
(2001) see commercial diplomacy as the work of diplomatic missions in support of the home country's business and finance sectors in pursuit of their economic success and the country's general objective for economic development. It includes the promotion of inward and outward investment and trade. Commercial diplomats supply intelligent information about export and investment opportunities and organize and help to host trade missions from home. A typically commercial diplomacy as (Rana, 2007) rightly observed, would not include the management of economic aid-either as a donor or a recipient country. This falls within the rubric of economic diplomacy. In the same vein, issues relating to the management of relations with international economic organisations such as the World Bank, International Monetary Fund (IMF), and the UN-regional Economic Commissions such as the Economic Commission for Asia and the Pacific (ESAP), Economic Commission for Africa (ECA) are within the jurisdiction of Economic Diplomacy. In sum, commercial diplomacy is principally concerned with trade promotion and investment. Issues on aid, foreign loans and institutional economic policies are better treated within the wider heading of economic diplomacy.

\subsection{Economic Diplomacy}

In modern diplomacy, the phrase economic diplomacy according to Baranay (2009) entails diplomatic activities geared towards increasing export, attracting foreign direct investments and participation in the activities of international economic organisations. It is also traditionally defined as the decision-making, policymaking and advocating of the sending state-business interests. Economic diplomacy requires application of technical expertise that analyzes the effects of a country's (Receiving State) economic situation on its political climate and on the sending State's economic interests. The Sending State and Receiving State, foreign business leaders as well as government officials collaborate on some of the most innovative issues in foreign policy, such as technology, the environment, and HIV/AIDS, as well as in the more traditional areas of trade and finance. Some of the specific qualities needed for a sound economic diplomacy are: versatility, flexibility, sound judgment and strong business skills (Ajaebili, 2011). Economic diplomacy involves both International and Domestic economic issues. This includes the rules for economic relations between states that have been pursued since the World War II. Consequent upon the rapid wave of globalization and the resultant interdependence, domestic economic issues have now been incorporated into the scope of economic diplomacy. This covers policies concerned with production, movement or exchange of goods, services, instruments (including official development assistance), money information and their regulation (Bayne and Woolcock (eds) 2007). ${ }^{3}$ Both State and non-state actors are involved in issues of economic diplomacy. Berridge and James (2003) state that:

to

"economic diplomacy is concerned with economic policy questions, including the work of delegations conferences sponsored by bodies such as the WTO" and include "diplomacy which employs economic resources, either as rewards or sanctions, in pursuit of a particular foreign policy objective." 4

Rana (2007) defines economic diplomacy as:

"the process through which countries tackle the outside world, to maximize their national gain in all the fields of activity including trade, investment and other forms of economically beneficial exchanges, where they enjoy comparative advantage. It has bilateral, regional and multilateral dimensions, each of which is important".

This implies that economic diplomacy incorporates the promotion of trade, investment and all other commercial exchanges covering the signing of treaties or agreements up to the conclusions of transactions between sovereign states; between a sovereign state and non-state actors and between non-state actors themselves. All international transactions are under the protection of economic diplomacy. This is why it is not really plausible for economic transactions to take place efficiently between two partners whose countries are not in economic diplomatic agreement. In economic diplomacy, the diplomat is a marketer engaged in the service of marketinging his home country to his host country. He organizes seminars and symposia trying to win the interest of the business population of his host country or international economic policy making organization. He is the essential link between the government and business community of his home country and the host country or organization. Thus economic diplomacy is the universal set from which we have commercial diplomacy as a subset.

\section{Background to Nigeria-China Relations}

Historically, the agreement for diplomatic relations between China and Nigeria was struck on the $10^{\text {th }}$ of February, 1971 and has been growing rapidly over the years (Utomi, 2012). Nigeria exports mostly crude oil to China and imports a large number of consumer goods such as electronics, clothes, textile materials etc.

In August 2001, Nigeria and China signed an agreement on investment promotion and protection. In April 2002, they signed another agreement for the avoidance of double taxation and the prevention of fiscal evasion as regards taxes on incomes (Gbadamosi and Ayodele), 2009). Drawing from the content of these 
agreements, Gbadamosi and Ayodele assert that the relationship between Nigeria and China is largely meant for China to source raw materials for her bourgeoning economy. They went further to say that this development was geared towards the win-win principle in FOCAC (Forum on China and Africa cooperation).

China has become the second largest oil importer, behind the USA. Thus accounting for about $40 \%$ of the world's oil demands (Utomi, 2012). Being the $6^{\text {th }}$ largest oil exporter in the world, Nigeria becomes a fertile ground on which to satisfy her vociferous oil demand. While some scholars admit that both countries depend on each other for the achievement of their goals at the international arena (Ekedegwa, 2010; Utomi, 2012). Others believe that it is triggering dependency for the Nigerian economy (Adekola, 2013); a position which informed this study as it is carefully analysed in the subsequent section. China needs the support of Nigeria in the United Nations and Nigeria has supported the return of Hong Kong to the People's Republic of China (Ekedegwa, 2010). Equally, China supports Nigeria in her quest to secure a permanent seat in an expanded Security Council of the United Nations.

This article does not propose as one of its goals, to portray China in a bad light. Neither can it deny that Nigeria has benefited from its relations with China. But the task taken up here is a wakeup call to acknowledge the prominence of trade as the chief reason for the penetration of Nigerian economy by China and to as well ring the danger bell that the overwhelmingly unequal commercial diplomacy between Nigeria and China does not prognosticate good for the transformation especially of the manufacturing sector of the Nigeria economy. China was involved in the launch of Nicomsat-1 which was later deorbited without any explanation. The China Nexim Bank was involved in the funding of five thermal stations in Nigeria: Ugheli, Geregu, papalanto, Aloiji and Omotosho Power plants (Tell, 2006). In the last visit of President Gooddluck Jonathan to China, Chinese government agreed to fund the $700 \mathrm{mh}$ and the $3050 \mathrm{mh}$ power plants in Mambila as well a promise to undertake the construction of a 7000mh in Nigeria (Radio Nigeria, 16/09/2013). China has been involved in the reconstruction and rehabilitation of Nigeria rail tract authority, Nigeria Railway Engineering Plc. and the Nigeria Railway integrated Plc. This saw the arrival of the Chinese Civil Engineering Construction Company in Nigeria (CCECC) (Tell, 2006). In october 2006, Nigeria signed a 2.5 dollar loan with China a substantial part of which was to be used in the refurbishment of the railway system. CCECC won the contract for the construction of the Abuja All-Africa games village in 2000 (Utomi, 2012). It built some 5000 housing units for international Athletes participating in the eighth annual All-Africa games in Nigeria. China operates over 30 solely owned companies or joint ventures in Nigeria and is actively involved in construction, oil and gas, technology, services and education sectors of the Nigerian economy. In sum, there has been an all-inclusive, rapidly growing diplomatic relations between Nigeria and China. But again, has this been a win-win situation? This task and others will be taken up in the next section.

\section{An Evaluation of Nigeria-China Commercial Diplomacy}

Since 1971 when the two countries signed the Joint Communiqué on the Establishment of Diplomatic Relations, trade relations between Nigeria and China have grown in the last decade from the limited and intermittent contact to an increasingly complex and expensive business engagement. The volume of trade between Nigeria and China grew at low levels until rapid growth turned China in 1993 from a net exporter of crude oil to the second-largest importer of crude oil in the world. The trade volume between the two countries grew by nearly 300 percent since 2004 and reached the peak of $\$ 7.2$ billion in 2008 . The trade volume between the two countries in 2009 reached $\$ 7.3$ billion and $\$ 7.7$ billion in 2010 respectively. With that level of trade, Nigeria is now the second biggest China trade partner in Africa, after South Africa (Ayoola, 2013). A flood in Nigeria by imports of Chinese goods in comparison with Nigeria's exports to China has resulted in a trade deficit with China and this is growing significantly in view of Nigeria's inability to offer the manufacturing sector a conducive environment to produce home grown alternatives to the China made goods. Nigerian markets are target for substandard products and because of stiff competition from these products; local manufacturing firms have withered away.

In an interview with trader in some part of Lagos by financial Vanguard, it was revealed that Chinese goods are highly subsidized for export which makes it possible for them to be sold at very cheap prices in Nigeria than similar products produced locally (Financial Vanguard, 2014). And because Nigerian consumers are highly sensitive to prices, they easily go for Chinese products as against the locally manufactured ones. The main outlet through which China made goods flood Nigerian markets is the popular China town market in Lagos from where other major markets in Lagos are penetrated and then to other parts of the country. Worse still, the dumping goods are also coming into the country through unapproved borders. Importers connive with Custom officials and other security agents to smuggle even contraband goods into the country. The Menace is so alarming and will continue to be if concerted efforts are not made to curtail the situation. Financial analysts have argued that the recent rebasing of the Nigerian Gross Domestic Product (GDP) which now puts the nation's economy at 26th in the world and first in Africa, bypassed the normal growth channel which is the 
manufacturing sector. Even more controversial is the fact that this momentous growth happened in the face of dwindling competitiveness rating of the country's economy by the World Economic Forum.

Further, there are complaints of cases of breach in signed Contractual Agreements, a good example is Everglades Agencies Ltd (a Nigerian Company) wrote to the Federal Ministry of Trade, Investment and Industry that Yanfeng Plastics Machinery co Ltd. (a Chinese company) has not complied with the contract Agreement signed by both parties in 2008 for installation, training of staff and supply of spare parts for machineries bought from the Chinese company. Secondly, the issue of Counterfeit products by Chinese companies of Nigerian products has become a serious menace. A case in point is the Products of Lee Group Nigeria Ltd (a footwear manufacturing company in Nigeria.

From the year 2000 to 2012 Nigeria has constantly experienced negative trade balance in her transactions with China. The most debilitating perhaps, is the fact that despite the relative increase of Nigeria's export to China, the negative trade balance continuous to surge on as the trade volume increases. While Nigeria's export increased from- N106,733,131,758 in 2009 to N216,506,104,707 in 2010, the negative trade balances sky rocketed from $\mathrm{N}-786,461,617,718$ in 2009 to $\mathrm{N}-884,274,401,292$ in the following year. (see Table 4). Between year 2000 and 2008 Nigeria lost a total of 18262.1 million dollars to trade deficit in a total transaction of 24785.7 million dollars (see table 3). Nigeria's imports from China rose by $10 \%$ to N1.21trn in 2012 from N1.1trn in 2010. However, exports to that country increased more than four times to N933.31bn in 2012 from the N216.51bn recorded in 2010. Though these figures show that Nigeria's exports to China are gradually stepping up with its imports level, one might argue that the increase in exports to China was as a result of the decline in oil exports to other countries such as the U.S. Thus, more oil was available to be exported to China. Therefore, the manufacturing sector is not responsible for this relative leap forward (see Table 4 in the Appendix).

Trade liberalization facilitated by the current wave of globalization has increasingly and inescapably integrated the economies of the world to the benefit of the developed world. The present competitiveness indicators of the Nigerian economy apparently exhibit acute inability to accommodate the pressure of globalization and trade liberalization being exploited by China (see Ayoola, 2013). The two countries are on different rums of the development ladder. Thus it is not unexpected that they relate at an unequally mutually beneficial level. Though the first world through the instrument of the World Bank and the International Monetary Fund (IMF) has weightily liberalized the economies of the world this has not denigrated the potency of diplomacy as an instrument of negotiations. Nigeria must employ this to shield her market from being a dumping centre for cheap and in some cases substandard Chinese goods.

Nigeria and China have signed a number of bilateral trade agreements and Memorandums of Understanding (MoUs). This has facilitated trade relations between the two countries over the years. But The Bilateral Trade Agreement (BTA) signed by both countries has lapsed and the Nigeria Federal Ministry of Trade, Investment and Industry is in the process of reviewing and forwarding a new BTA through diplomatic channel to China for negotiation. The MoU signed on Economic Cooperation Agreement between Nigeria and Guandong Xinguang International Group of China is still valid and remains valid, unless either Party gives written notice to terminate the MoU. But instruments of ratification were not exchanged by both countries so that the Agreement can come into effect. Therefore, it is subject to renegotiation. This is a window of opportunity and Nigeria has to maximally utilize this to renegotiates the terms of agreement for the benefit of its domestic economy. Exports to China include bituminous minerals, Sesame seeds, rubber, oil and natural Gas, dry cassava chips, liquefied and polyethylene.

While the imports from China include unglazed ceramics, vans wall tiles, motorcycles, machinery equipment, auto parts, tyres, chemical products, textiles and garments footwear, cement, oil, etc. (see Table 2 and 3)

\subsection{Bilateral Trade Agreements and MoUs with China}

In order to build investors' confidence, the two countries signed the following Agreement and MoUs. These are:

i) The Bilateral Trade Agreement signed on 27th August, 2001;

ii) Memorandum of Understanding on Investment Cooperation between the Ministry of Commerce of both Countries signed on 28th February, 2006; and

iii) Memorandum of Understanding on Economic Cooperation Agreement between Nigeria and Guandong Xinguang International Group of China on 15th March, 2006.

iv) Nigeria and China signed Investment Promotion and Protection Agreement (IPPA) in 2001. It was ratified on 31st December, 2002.

v) Memorandum of Understanding between Federal Ministry of Industry Trade and Investment of the Federal Republic of Nigeria and Asia and Africa International Investment Company on Investment in Automobile, Exhibition Centres, Construction of Industrial Zone and Eco- Agriculture Zone signed on 11th July, 2013.

Source: Federal Ministry of Industry, Trade and Investment, Nigeria, 2014. 


\section{Conclusion}

Although the diplomatic relations between Nigeria and China is all encompassing, the major content of this relation is commercial diplomacy. Unfortunately, Nigeria is not maximizing this to the benefit of the manufacturing sector due to structural deficiency and corruption resulting in rapid decline in the performance of the domestic manufacturing sector. Nigeria has to use the window for negotiation in the bilateral trade agreement so as to be able to impose tariffs for the protection of the dying domestic production. Effective border patrol must be encouraged so as to checkmate the importation of substandard goods into the country. Nigeria is in dire need of investment not trade. This will translate into job creation for the teaming unemployed population and consequently poverty eradication.

\section{Notes and References}

[1] D. Lee and D. Hudson, The old and new significance of political economy in diplomacy, Review International Studies, British International Studies Association, 30, 2004, 343-360

[2] E. O. Ogunkola, A. S. Bankole and A. Adewuyi, China-Nigeria economic relations: AERC scoping studies on China-Africa relations, a revised report submitted the Africa economi research consortium (AERC), University of Ibadan, Ibadan, Nigeria, 2008, 3-16

[3] O.G. Adekola, New perspective to Nigeria's foreign policy towards China, IOSR journal of humanities and social science, 6 (5) 2013, 01-06

[4] A. Osakwe, China-Nigeria relations: Nigerian Niger delta and continent wide pattern, International Affairs Review, Vol. 1, Number 4.2012, 6-47

[5] P. Utomi, China and Nigeria, 2012, retrieved from http://080603 utomi nigeriachina, September 2013

[6] U.O. Akeem, Performance evaluation of foreign trade and economic growth in nigeria, Journal of Finance and Accounting vol.2, No 2, 2011, 2222-2847

[7] D. Nabine, The impact of Chinese investment and trade on Nigeria, ATP Work in Progress No 77 of Economic Commission for Africa Economic Growth, 2009

[8] R.K. Ayeni An assessment of profit function of manufacturing firms in Nigeria during global economic depression: A panel Approach, Ozean Journal of Social Sciences 5(2), 2012, 41-48

[9] ${ }^{1}$ www.wikipedia encyclopedia economic diplomacy, http//en.wikipedia.org/wiki/economic Diplomacy, 2013

[10] 2 www.wikipedia encyclopedia economic diplomacy, http//en.wikipedia.org/wiki/economic Diplomacy, 2013 p.2

[11] J. Melissen, Innovation in diplomatic practice (London: Macmillan, 1999)

[12] R. Sanar and L. Yiu, International economic diplomacy: mutations in postmodern times, key note presentation given during the 2001 annual meeting of director of diplomatic academics, University of Leicester, Vienna, Austria, 2001, 1-41

[13] O. Naray, Commercial diplomacy: A conceptual overview Paper presented at the $7^{\text {th }}$ World Conference TPOS- The Hague, The Netherland, 2008 1-16

[14] S.K. Rana. Economic diplomacy: The experience of developing countries, in B. Nicholas and W. Stephen .Eds. The New Economic Diplomacy: Decision making and negotiation in international economic relations, 2ndedition. (London: Ashgate, 2007)

[15] P.Baranay Modern economic diplomacy a publication of the economic diplomatic club, Latvia, 2009

[16] C.N. Ajaebili, The option of diplomacy in Nigeria's foreign policy, international journal of humanities and social science, 1(17) (Special issue) 2011, 277-280

[17] ${ }^{3}$ www.wikipedia encyclopedia economic diplomacy, http//en.wikipedia.org/wiki/economic diplomacy, 2013, p.1

[18] www.wikipedia encyclopedia economic diplomacy, http//en.wikipedia.org/wiki/economic diplomacy, 2013, p.1

[19] A. Gbadamosi and A. Oniku, The strategic implications of China's economic pacts with sub-Saharan African countries: The case of Nigeria conference of the international journal of Arts and sciences, 1(18) 2009, 115-130

[20] O. L Ekedegwa, Sino-Nigeria economic relations under the Obasanjo administration, Ilorin journal of history and international studies University of Ilorin, online, 104-118

[21] Tell Magazine, Lagos, January $31^{\text {st }}, 2006$

[22] Radio Nigeria network news 16/09/2013

[23] T .J. Ayoola, Nigeria-China trader elations: Implications on the Nigerian domestic economy, research journal of finance and accounting, 4(17), 2013, 98-104

[24] National Bureau of Statistics, Nigeria

[25] Federal Ministry of Industry, Trade and Investment, Nigeria

\section{Appendix}

Details Of Top 10 Exports To China In The Year 2012.

\begin{tabular}{|l|c|}
\hline Products & Values(N) \\
\hline Petrol, oils and oils obtained from bituminous minerals, crude & $446,860,422,704$ \\
\hline Tech. specified nat. rubber, in pry. Forms/in plates, etc & $162,418,890,989$ \\
\hline Natural gas, liquefied & $161,442,696,809$ \\
\hline Motor spirit (gasoline) regular & $69,569,320,416$ \\
\hline Imported motocycles and cycles, imported CKD by est. & $46,348,298,843$ \\
\hline manuf >50cc<250 & $38,583,804,859$ \\
\hline Mach for the reception, conversion and transmission of voice & $28,466,490,382$ \\
\hline New pneumatic tyres, of rub. Of a kind used on buses/lorries & $26,129,432,787$ \\
\hline Herbicides, ant-sprouting products and plant-growth regulators & \\
\hline Unglazed ceramic flags and paving, hearth or wall tiles etc & $21,380,548,525$ \\
\hline And accessories of motorcycles (incl. mopeds) & \\
\hline
\end{tabular}

Table 1. Source: National Bureau of Statistics (2012) 
Details Of Top 10 Imports From China In The Year 2012

Products

Imported motorcycles and cycles, imported CKD by est. manuf

$>50 \mathrm{cc}<=250$

Values $(\mathrm{N})$

Mach 4 the reception,conversion \& transmission or

regeneration of voice,

$46,348,298,843$

Herbicides, ant-sprouting products and plant- growth regulators

$38,583,804,859$

Unglazed ceramic flags and paving, hearth or wall tiles etc

$26,129,432,787$

Parts and accessories of motorcycles (inclu. Mopeds)

$22,273,713,309$

F/cold-rolled i/stell, coils, width $>=600 \mathrm{~mm},<0.5 \mathrm{~mm}$ thick

$21,380,548,525$

Generating sets with spark-ignition internal combustion piston

engines ck

$18,250,572,494$

Other aluminum plates, sheets of thickness $>0, .2 \mathrm{~mm}$, alloyed

$17,465,833,033$

Base stations

$16,581,905,720$

$16,282,866,351$

Table 2. Source: National Bureau of Statistics, Nigeria (2012)

Nigeria-China trade statistics from 2000-2008 (In USDmillion)

\begin{tabular}{|c|c|c|c|c|}
\hline Year & Export & $\begin{array}{l}\text { Import } \\
\text { of trade }\end{array}$ & Volume of Trade & Trade balance \\
\hline & (US\$millions) & (US\$million) & (US\$millions) & US\$milions \\
\hline 2000 & 292.9 & 563.9 & 860 & -271 \\
\hline 2001 & 227.4 & 917.2 & $1,144.6$ & -227.4 \\
\hline 2002 & 121.3 & 1047.1 & $1,168.4$ & -926.4 \\
\hline 2003 & 71.7 & $1,787.5$ & $1,859.2$ & -1715.8 \\
\hline 2004 & 462.6 & $1,719.3$ & $2,181.9$ & -1256.7 \\
\hline 2005 & 527.1 & $2,305.3$ & $2,832.4$ & -17.78 .2 \\
\hline 2006 & 280.0 & $2,855.7$ & $3,133.5$ & -2575.7 \\
\hline 2007 & 537.5 & $3,800.2$ & $4,337.7$ & -3262.7 \\
\hline 2008 & 509.9 & $6,758.1$ & 7268.0 & -6248.2 \\
\hline Total & 3030.4 & 20035 & 24785.7 & -18262.1 \\
\hline
\end{tabular}

Table 3. Source: Ayoola, 2013; World trade data.

Nigeria-China trade statistics from 2009-2012 (In Naira Value)

\begin{tabular}{|l|l|l|c|c|}
\hline Year & Exports & Imports & Volume of Trade & Trade Balance \\
\hline 2009 & $106,733,131,758$ & $893,194,749,476$ & $999,927,881,234$ & $-786,461,617,718$ \\
\hline 2010 & $216,506,104,707$ & $110,0788,050,599$ & $326,584,155,306$ & $-884,274,401,292$ \\
\hline 2011 & $392,574,877,537$ & $1,460,988,039,990$ & $1853,562,917,527$ & $-1068,413,162,453$ \\
\hline 2012 & $933,306,451,356$ & $1,209,774,086,424$ & $2,143,080,537,780$ & $-276,467,635,068$ \\
\hline
\end{tabular}

Table 4. Source: Federal Ministry of Industry, Trade and Investment, Nigeria, 2014.

\section{About The Author}

IBRAHIM Abu Akoh is currently a postgraduate (Msc) student of International Relations in the Department of Political Science and International Studies, Ahmadu Bello University, Zaria, Kaduna state, Nigeria. 